\title{
GAMBARAN BRAND EXPERIENCE DAN BRAND LOVE IPHONE PADA KOMUNITAS FANSPAGE FACEBOOK IPHONE INDONESIA
}

\author{
Silvana Hanifah \\ Universitas Pendidikan Indonesia \\ silvanahanifah95@student.upi.edu \\ Agus Rahayu \\ Universitas Pendidikan Indonesia \\ agusrahayu@upi.edu \\ Puspo Dewi Dirgantari \\ Universitas Pendidikan Indonesia \\ puspodewi@upi.edu
}

\begin{abstract}
ABSTRAK
Tujuan - Tujuan penelitian ini adalah untuk mengetahui gambaran brand experience dan brand love. Desain/metodologi/pendekatan - Desain penelitian ini adalah cross sectional. Penelitian ini menggunakan pendekatan deskriptif dengan metode explanatory survei unit analisis sebanyak 83 responden. Pengumpulan data dengan menggunakan kuesioner. Teknik analisis yang digunakan adalah teknik deskriptif dengan menggunakan distribusi frekuensi.

Temuan - Berdasarkan hasil penelitian mneggunakan analisis deskriptif, didapatkan hasil bahwa brand experience berada pada kategori tinggi dengan skor 94,18\% dan brand love berada dalam kategori cukup tinggi dengan skor $64,60 \%$.

Orisinalitas/nilai - Penelitian ini dilakukan pada industri telekomunikasi dengan objek penelitiannya adalah sebuah produk dari merek terkenal. Dimensi dan indikator yang digunakan untuk mengukur gambaran variabel yang diteliti merupakan teori consumer-brand relationship
\end{abstract}

Kata kunci: Brand experience, brand love, iphone

Jenis Artikel: Studi Kasus

\section{ABSTRACT}

Purpose - The purpose of this study is to see the description of brand experience and brand love.

Design / methodology / approach - The design of this study is cross sectional. This research uses descriptive approach with survey explanatory method as much as 83 respondents. A questionnaire was used as a research instrument to collect data from respondents. Analytical technique used is descriptive technique by using frequency table.

Findings - Based on the results of the research using descriptive analysis, the result of the experience brand is in the high category with with a score of representative $94.18 \%$ and the love brand is in high category with with a score of representative $64.60 \%$.

Originality / value - This research provides is condusted on telecommunication industry with the object of research is a product from famous brand. The dimensions and indicators used to measure of variablethe are theories consumer-brand relationship.

Keywords: Brand experience, brand love, iphone

Article Type : Case Study 


\section{PENDAHULUAN}

Merek memberikan peranan penting bagi perusahaan sehingga perlu dikelola, dikembangkan, diperkuat, dan ditingkatkan kualitasnya untuk memberikan keuntungan kompetitif yang berkelanjutan (K. Keller, 2013; Kotler \& Armstrong, 2013). Membangun merek membutuhkan investasi besar dalam komunikasi, distribusi, dan kegiatan lainnya (Fischer, Völckner, \& Sattler, 2010).

Industri telekomunikasi dan media di Indonesia terus berkembang. Media merupakan alat atau sarana komunikasi. Sedangan telekomunikasi adalah teknik pengiriman atau penyampaian infomasi, dari suatu tempat ke tempat lain (Anggraeni \& Rachmanita, 2015).

Ranking pertama yang ditempati oleh Iphone pada best global brand tidak otomatis membuat Iphone mempunyai market share terbesar pada industri smartphone. Samsung menguasai pasar sebesar $24.8 \%$ di tahun 2015 dan 22.2\% di tahun 2016, sedangkan Iphone berada pada posisi kedua hanya mampu menguasai pasar sebesar $16.8 \%$ pada tahun 2016 karena dihadapkan pada banyaknya merek baru yang memasuki pasar smartphone (TrendForce.com).

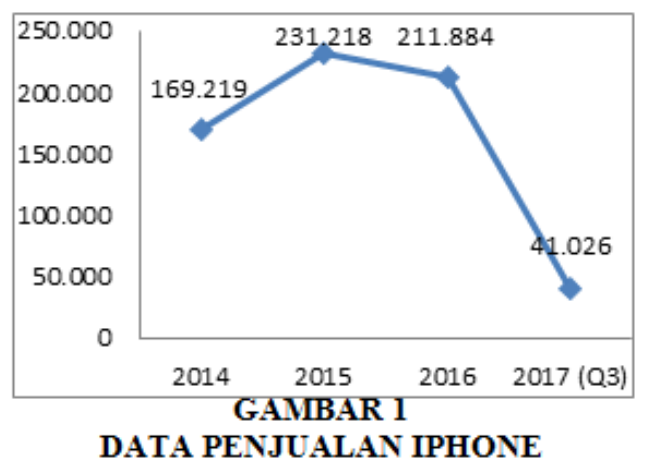

Gambar 1 menunjukkan penjualan iPhone mengalami penurunan pada tahun 2016 dan 2017. Penurunan terlihat signifikan ketika memasuki kuartal ke-2 di tahun 2016, perbedaan penjualan dibandingkan tahun 2015 pada kuartal yang sama sebesar 9,98 juta unit, pada kuartal ke-3 tahun 2016 mengalami penurunan sebanyak 7,13 juta unit dan pada kuartal ke-4 mengalami penurunan sebanyak 2,54 juta unit pada kuartal yang sama di tahun 2015. Hal ini dapat mengindikasikan berkurangnya pelanggan dalam mencintai merek. Seperti di ungkapkan oleh (Kang, 2015) bahwa penjualan produk dari merek tertentu dapat disebabkan oleh tidak adanya kecintaan pelanggan terhadap merek sehingga beralih memilih produk merek lain.

Tabel 1

Net Emotional Value Smartphone

\begin{tabular}{lccc}
\hline \multirow{2}{*}{ Perusahaan/Merek } & \multicolumn{3}{c}{ NEV } \\
\cline { 2 - 4 } & $\mathbf{2 0 1 5}$ & $\mathbf{2 0 1 6}$ & $\mathbf{2 0 1 7}$ \\
\hline Iphone & 7,935 & 6,744 & 6,588 \\
Samsung & 5,956 & 4,838 & 5,441 \\
Xiaomi & & 4,895 & 3,627 \\
LG & 6,160 & 5,035 & 4,932 \\
Sony & 4,500 & 3,437 & - \\
Nokia & 4,861 & 3,784 & - \\
Blackberry & 3,927 & 2,885 & - \\
\hline Sumber : Majalah SWA Edisi 22 Tahun 2015-2017
\end{tabular}

Net Emotional Value (NEV) bertujuan untuk mendeteksi pengalaman mana yang paling mengesankan (menyentuh emosi) saat berinteraksi dengan sebuah merek dan layanannya sehingga mempengaruhi tingkat kepuasan pelanggan. Pada survei NEV dipertimbangkan berbagai moment of truth (touch point) yang menunjukkan rasa responden terhadap pengalaman yang diterimanya dari sebuah produk/merek dan layanannya. Responden ditanyakan pengalamannya dari setiap interaksi, baik pengalaman positif maupun pengalaman negatif. Tabel 1 menunjukkan bahwa Iphone pada tahun 2016 dan tahun 2017 mengalami penurunan, mengindikasikan bahwa pengalaman pelanggan terhadap merek semakin berkurang, iphone kurang dapat mempertahankan touch point paling penting yang paling berpengaruh.

Nilai dari net emotional value (NEV) diatas seharusnya menjadi salah satu acuan bagi perusahaan, emosi yang terbangun antara pelanggan dengan merek secara berkesinambungan dapat menumbuhkan loyalitas pelanggan. Nilai NEV yang bagus harus diimbangi dengan nilai Net Promoter Score (NPS) yang baik pula. Net Promoter Score (NPS) merupakan survei kepada pelanggan apakah mereka benar-benar merasa puas (loyal) sehingga mereka memiliki kecenderungan paling tinggi untuk melakukan pembelian kembali dan menjadi promoter untuk merekomendasikan sebuah merek kepada teman atau keluarga.

Konsumen membentuk pilihan berdasarkan pengalaman dari merek yang ditawarkan. Pengalaman-pengalaman jangka panjang dengan merek bisa disimpan dalam memori serta mempengaruhi loyalitas dan kepuasan pelanggan (Kataria, 2015). Brand experience menjadi faktor yang mendominasi karena selain peduli dengan bagaimana suatu brand dapat melaksanakan fungsinya, konsumen menikmati saat-saat atau pengalaman berinteraksi dengan brand tersebut sehingga 
memberikan stimulasi terhadap emosi dan perasaan kecintaan terhadap merek (K. Keller, 2013). Bagaimanapun, kepuasan saja tidak cukup untuk memberikan rasa cinta, penelitian membuktikan bahwa menyenangkan pelanggan, kejutan, dan kegembiraan berkaitan dengan pengalaman yang diberikan oleh merek memberikan dampak positif bagi brand love (Roy, Eshghi, \& Sarkar, 2013).

Tujuan dari penelitian ini adalah untuk melihat gambaran dari brand experience dan brand love.

\section{KAJIAN PUSTAKA}

Pemasaran adalah proses pembentukan hubungan terpadu yang bertujuan untuk memberikan nilai secara tuntas mengenai barang maupun jasa dalam kaitannya memenuhi kebutuhan dan keinginan manusia (Kotler \& Keller, 2016). Perkembangan pemasaran menjadi beberapa bidang yaitu perilaku konsumen, strategi pemasaran jasa dan strategi merek (Rahayu \& Wibowo, 2013). Pemasaran strategis merupakan proses pengembangan market-driven strategy, dengan mempertimbangkan lingkungan bisnis yang terus berubah sesuai dengan kebutuhan pelanggan dan bertujuan untuk memberikan nilai yang unggul. Fokus pemasaran strategis lebih berpusat pada kinerja organisasi dibandingkan usaha untuk meningkatkan penjualan. Pemasaran strategis menghubungkan organisasi dengan lingkungan dan memandang pemasaran sebagai tanggung jawab dari keseluruhan bisnis tersebut (Cravens \& Piercy, 2013:15).

Pemasaran strategis terdiri dari beberapa proses diantaranya: 1) markets, segments, and customer value, 2) designing market-driven strategies, 3) market-driven program development dan 4) implementing and managing market-driven strategy (Cravens \& Piercy, 2013:16); (Puspo Dewi Dirgantari, 2016). Salah satu proses dalam pemasaran strategis yaitu market-driven program development yang mengacu pada penargetan pasar dan strategi positioning, untuk memandu pilihan strategi dalam program pemasaran. Strategi pemasaran mengacu pada pola terpadu organisasi untuk menentukan keputusan penting yang menyangkut perilaku pemasaran atau tindakan yang ditujukan pada pelanggan untuk efek afektif tertentu, kognitif dan kecenderungan perilaku pada mereka menuju penawaran produk dalam rangka memfasilitasi mereka terlibat dalam menghasilkan pendapatan transaksional dan pertukaran relasional dengan organisasi dan dengan demikian memungkinkan organisasi untuk mencapai tujuan tertentu (P D Dirgantari, Rahayu, \& Hurriyati, 2016)

Strategi program pemasaran menerapkan strategi positioning dengan menggunakan program marketing mix yang terdiri dari: 1) strategic brand management, 2) value-chain, 3) pricing dan 4) promotion (Cravens \& Piercy, 2013:19). Strategic brand management melibatkan desain dan implementasi program pemasaran serta kegiatan untuk membangun, mengukur, dan mengelola merek (Keller, 2013:58). Merek merupakan harta tidak berwujud yang berperan penting bagi perusahaan karena dapat membawa beberapa keuntungan serta merupakan dasar dari keunggulan kompetitif perusahaan (Arora \& Neha, 2016). Langkah-langkah utama dalam strategic brand management terdiri dari: 1) identifying and developing brand plans, 2) designing and implementing brand marketing programs, 3) measuring and interpreting brand performance, dan 4) growing and sustaining brand equity (Keller, 2013:58). Langkah pertama strategic brand management dimulai dengan mengidentifikasi dan melakukan pemahaman yang jelas tentang konsep merek dan bagaimana merek harus diposisikan terhadap pesaing. Langkah selanjutnya setelah melakukan identifikasi terhadap merek, dilakukan pengembangan perencanaan merek dengan tujuan semakin kuatnya merek.

Langkah yang harus diperhatikan dalam membangun merek yaitu designing and implementing brand marketing programs, kemudian personalizing marketing menjadi kunci untuk beradaptasi dengan keinginan konsumen karena kecepatan perkembangan media dan internet menjadikan konsumen memiliki banyak kebutuhan khusus yang harus dipahami. Selanjutnya, konsep experiental marketing dan relationship marketing (K. Keller, 2013) mencoba memberikan pengalaman merek yang lebih menyeluruh dan holistik untuk menciptakan ikatan konsumen yang lebih kuat. Experiental marketing mengembangkan produk bukan hanya dengan memberikan nilai dan manfaat saja tetapi juga memberikan pengalaman unik dan menarik bagi konsumen (Ekaputri, Rahayu, \& Wibowo, 2016). Schmitt (2009) memaparkan terdapat lima perbedaan marketing experience menjadi semakin penting untuk memberikan persepsi pelanggan mengenai merek: 1). Sense marketing, menarik perasaan pelanggan dengan bentuk, suara, sentuhan, bau dan rasa, 2). Feels marketing, menarik perasaan batin dan emosi pelanggan, mulai dari suasana hati yang positif dengan merek, 3). Think marketing, 
memberikan pemahaman kepada pelanggan dalam memecahkan masalah yang melibatkan pengalaman dan kreativitas pelanggan, 4). Act marketing, tujuan fisik gaya hidup, kebiasaan dan interaksi, 5). Relate marketing, membentuk pengalaman dengan mempertimbangkan keinginan individu untuk menjadi bagian dari konteks sosial seperti komunitas.

Brand experience menjadi bagian penting dari experiential marketing, konsumen menciptakan pengalaman dengan merek mulai dari pencarian produk, memilih dan membeli produk di toko, melakukan interaksi dengan layanan pelanggan sampai menggunakan produk sehingga pengalaman tersebut dapat memberikan nilai bagi merek (Wibowo, n.d.)

Menurut Braskus, et. al. (2009) brand experience didefinisikan sebagai sensasi, perasaan, kognisi dan tanggapan konsumen yang ditimbulkan oleh merek, terkait rangsangan yang ditimbulkan oleh desain merek, identitas merek, komunikasi pemasaran, orang dan lingkungan merek tersebut dipasarkan. Brand experience didefinisikan sebagai sensasi, perasaan, kognisi, dan tanggapan perilaku yang ditimbulkan oleh stimulus yang berhubungan dengan merek merupakan bagian dari desain merek, identitas, kemasan, komunikasi, dan lingkungan (Evans, 2011). Pendapat (Smith \& Hanover, 2016) "Pengalaman merek adalah persepsi, sikap, kognitif, dan reaksi emosional konsumen yang dipicu oleh stimulus yang berhubungan dengan merek termasuk produk, desain merek, kemasan, penjualan, pembelian dan pengalaman lingkungan yang dibuat oleh perusahaan.".

(Chen, Chen, \& Ma, 2016). Braskus et al., (2009) (Saari \& Mäkinen, 2017) berpendapat bahwa brand experience dapat dibentuk dari empat dimensi, yaitu 1) Sensory experience, 2) Affective experience, 3) Behavioral experience, 4) Intellectual experience. Penambahan dimensi muncul pada penelitian (Nysveen, Pedersen, \& Skard, 2012), terdapat lima dimensi penting untuk membangun brand experience, diantaranya: 1). Sense, rangsangan yang masuk pada indera penglihatan, pendengaran dan perasaan mengenai merek, 2). Feel, perasaan timbul dari pelanggan karena dampak mengkonsumsi merek, seperti senang dan bangga, 3). Act, kebiasaan yang muncul ketika berhubungan dengan merek, 4). Think, rangsangan berpikir dari merek kepada pelanggan, 5). Relate, hubungan dari interaksi antara merek dan pelanggan. Penelitian lain pada industri fashion menggunakan tiga dimensi yang dijadikan indikator brand experience, yaitu 1) Behavioral experience, 2) Cognitive experience dan 3) Affective experience (Chu \& Kim, 2011). Pengalaman bukan hanya diberikan oleh produk (Kazancoglu, 2014), membangun city experience berdasarkan dimensi social activities \& leisure time experience, affective experience, taste experiences, disturbing sensory experience, and nature-related experience

Dimensi-dimensi tersebut menjadikan brand experience adalah sebuah rasa, sensasi, hubungan dan kebiasaan yang menjadi hasil dari pembentukan banyak stimuli yang terbentuk ketika terjadi interaksi dengan pelanggan secara langsung ataupun tidak langsung (Iglesias, Singh, \& Batista-Foguet, 2011).

Sedangkan, brand love berasal dari tahap pertama Strategic Brand Management Process, yaitu Identifying \& Developing Brand Plans. Proses strategic brand management dimulai dengan pemahaman yang jelas tentang apa yang akan mewakili merek dan bagaimana hal itu dapat diposisikan dan bersaing dengan merek lain. Brand relationship yang terdiri dari behavioral loyalty, attitude attachment, sense of community, dan active engagement mencirikan hubungan ddengan merek yang memungkinkan untuk menciptakan loyalitas, keterikatan, serta keterlibatan yang aktif antara merek dengan pelanggan. Bagian kedua dari brand relationship yaitu attitude attachment. Beberapa peneliti sering mengkategorikannya sebagai brand love (K. L. Keller, 2013)

Hubungan yang tercipta antara pelanggan dengan merek dan melibatkan emosional menunjukkan kecintaan terhadap merek. Ahuvia, Batra dan Bagozzi (2008:178) menyatakan bahwa, brand love mencakup aspek yang terlibat dengan merek, (setidaknya) merasa puas terhadap merek, dan memiliki sikap positif terhadap merek.

Carroll dan Ahuvia menyatakan bahwa brand love adalah campuran emosi dan gairah dari seseorang untuk sebuah merek, brand love juga sebagai tingkat keterikatan emosional dan cinta yang menyatakan bahwa konsumen puas terhadap merek ((Rodrigues \& Reis, 2013) dan (Sallam, 2014)). Pengertian lain, brand love is conceptualized here as a mode satisfaction, i.e., a response experienced by some, but not all, satisfied consumers (Airey, 2012). Pengertian brand love tersebut tertuju pada sebuah tingkatan kepuasaan konsumen yang menghasilkan sikap konsumen untuk mencintai merek akan tetapi tidak semua konsumen merasakan sebuah kepuasaan untuk mencintai sebuah merek. Pendapat lain mengungkapkan mengenai definisi, brand love is defined as the degree of passionate emotional attachment a 
satisfied consumer has for a particular trade name. Brand love merupakan tingkat ikatan emosional yang penuh gairah kepuasaan konsumen untuk memiliki sebuah merek (Kusume, 2013).

Brand love dapat didefinisikan sebagai keinginan terhadap suatu merek, sikap mengikat terhadap merek tertentu, hasil positif dari suatu merek, respon positif terhadap suatu merek, pembuktian untuk menyukai merek tertentu (Kucuk, 2016). Pengalaman konsumen yang merasa puas dengan merek, tidak hanya mengarah kepada loyalitas tetapi mengacu pada penilaian yang lebih kognitif, emosi dan perilaku jangka panjang (Batra, Ahuvia, \& Bagozzi, 2012; Fetscherin \& Conway, 2014). Brand love merupakan hubungan jangka panjang yang dibangun dengan fokus dan efektif, Paula Rodrigues menyebutkan aspekaspek brand love meliputi: ketertarikan dengan merek, keterikatan dengan merek, evaluasi positif terhadap merek, emosi positif terhadap merek dan pernyataan cinta kepada suatu merek (Rodrigues \& Reis, 2013).

Steinberg, 1986 mengungkapkan teori cinta antar pribadi dengan konteks konsumsi, brand love muncul terdiri dari tiga dimensi:

(1) Passion, mengacu pada daya tarik fisik, penyempurnaan seksual, dan terkait fenomena dalam hubungan cinta. Komponen passion termasuk dalam lingkup motivasi dan bentuk lain dari passion yang mengarah pada pengalaman dalam hubungan cinta. (2) Intimacy mengacu perasaan kedekatan, keterhubungan, dalam hubungan cinta kasih. (3) Decision atau Commitment, (Kim, 2007) menyatakan bahwa decision/ commitment meliputi dua aspek yakni, jangka pendek dan jangka panjang. Pada jangka pendek decision/ commitment merupakan keputusan atau komitmen seseorang untuk mencintai orang lain, dan dalam jangka panjang ia akan memelihara hubungan cinta tersebut setiap waktu.

Dimensi brand love yang diungkapkan oleh (Batra et. al. 2012, 2014, 2016) yaitu:

(1) Self brand integration, Objek cinta terintegrasi ke dalam diri konsumen, mengekspresikan nilai-nilai yang dipegang teguh dan identitas kelompok yang penting, dan memberikan penghargaan intrinsik. Serta, konsumen sering berpikir dan berbicara tentang obyek cinta. (2) Passion Driven Behaviors, Konsumen akan melakukan investasi berupa uang dan waktu, serta memiliki semangat yang penuh terhadap objek yang dicintai karena sering berinteraksi. (3) Positive Emotional Connection, Emosi dan pengalaman antara pelanggan dengan objek, memiliki hubungan positif ketika mereka berpikir tentang objek atau ketika menggunakan objek. (4) Long-term Relationship, merek akan digunakan untuk waktu yang lama hingga menjadi bagian hidup jangka panjang (5) Anticipated Separation Distress, kecemasan, khawatir perasaan takut ketika berpisah. (6) Attitude Valence, sering membicarakannya kepada orang lain, sangat sering memikirkannya, merasakan kasih sayang. Terdapat 5 karakteristik kecintaan merek antara lain : 1) Passion for a brand (Gairah untuk merek), 2) Brand attachment (Lampiran merek), 3) Positive evaluation of the brand (Evaluasi positif dari merek), 4) Positive emotions in response to the brand (Emosi positif dalam menanggapi merek), 5) Declarations of love toward the brand (Deklarasi cinta terhadap merek) (Albert et al., 2008: 1064).

Pengukuran brand love pada penelitian ini didasarkan kepada kombinasi dari dimensi penelitian sebelumnya yang dianggap dapat menggambarkan tingkat kecintaan terhadap merek, yaitu sebagai berikut: 1) Self-brand Integration, 2). Passion Driven Behaviors, 3). Positive Emotional Connection 4). Longterm Relationship 5). Anticipated Separation Distress dan 6). Attitude Valence

\section{METODE PENELITIAN}

Penelitian ini dilakukan untuk mengetahui gambaran brand experience dan gambaran brand love. Variabel independen yang terdapat pada penelitian ini yaitu brand experience dengan dimensi sensory experience, affective experience, intellectual experience dan behavioral experience. Sedangkan variabel dependen yaitu brand love dengan dimensi self brand integration, passion driven behaviors, positive emotional connection, long-term relationship, anticipate separation distress dan attitude valence.

Unit analisis pada penelitian ini adalah pengguna Iphone yang tergabung dalam komunitas fanspage facebook Iphone Indonesia. Penelitian ini dilakukan pada kurun waktu kurang dari satu tahun, sehingga teknik pengumpulan data yang dilakukan pada penelitian ini adalah cross-sectional method (Maholtra, 2010). Sampel yang digunakan dalam penelitian ini sebanyak 83 responden. Teknik pengumpulan data yang digunakan adalah kuesioner dan studi kepustakaan. Sedangkan teknik analisis data yang dilakukan adalah analisis deskriptif dengan menggunakan distribusi frekuensi. 


\section{HASIL PENELITIAN DAN PEMBAHASAN}

Konsumen membentuk pilihan berdasarkan pengalaman dari merek yang ditawarkan. Pengalaman-pengalaman jangka panjang dengan merek bisa disimpan dalam memori serta mempengaruhi loyalitas dan kepuasan pelanggan (Kataria, 2015). Berikut merupakan penjelasan hasil temuan gambaran brand experience dan brand love.

Berdasarkan hasil pengolahan data yang telah dilakukan melalui penyebaran kuesioner pada Komunitas Fanpage Facebook Iphone dapat diukur melalui perhitungan skor dimensi dari brand experience. Skor total brand experience sebesar 8.208 sedangkan skor ideal brand experience itu sendiri adalah 8715.

Secara ideal skor yang diharapkan untuk jawaban pengguna iphone pada komuntas fanspage facebook Iphone Indonesia terhadap pertanyaan nomor 1 sampai dengan 15 adalah 8.715. Berdasarkan perhitungan di atas menunjukan nilai yang diperoleh adalah sebesar 8.208 atau persentasenya sebesar $94,18 \%$ dari skor ideal yaitu 8.715 , dengan perbandingan ini menunjukan bahwa brand experience pada iphone berada pada kategori tinggi. Konsumen mempercayai bahwa sensory experience, affective experience, intellectual experience dan behavioral experience sebagai karakteristik brand experience.

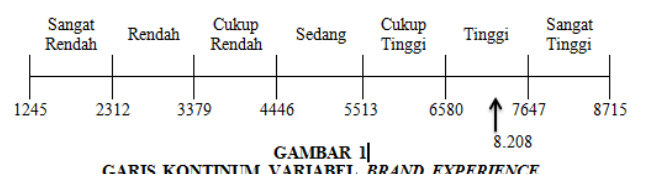

Secara keseluruhan variabel brand experience (X) yang terdiri dari sensory experience, affective experience, intellectual experience, dan behavioral experience. Dapat diketahui kedudukannya berdasarkan skor yang di dapat dari rekapitulasi data dimensi dari variabel brand experience (X) tersebut dapat dilihat dari Tabel 1 berikut:

Tabel 2

Rekapitulasi Tanggapan Mengenai Dimensi

Brand Experience

\begin{tabular}{|c|c|c|c|c|}
\hline No & Dimensi & $\begin{array}{l}\text { Perolehan } \\
\text { Skor }\end{array}$ & $\begin{array}{l}\text { Skor } \\
\text { Rata- } \\
\text { rata }\end{array}$ & $(\%)$ \\
\hline 1. & $\begin{array}{l}\text { Sensory } \\
\text { Experience }\end{array}$ & 2416 & 483,2 & 34,82 \\
\hline 2. & $\begin{array}{l}\text { Affective } \\
\text { Experience }\end{array}$ & 1816 & 454 & 26,18 \\
\hline 3. & $\begin{array}{l}\text { Intellectual } \\
\text { Experience }\end{array}$ & 1954 & 488,5 & 28,18 \\
\hline 4. & $\begin{array}{l}\text { Behavioral } \\
\text { Experience }\end{array}$ & 750 & 375 & 10,82 \\
\hline \multicolumn{2}{|c|}{ Total } & 6936 & 1800,7 & 100 \\
\hline
\end{tabular}

Tabel 2 merupakan hasil pengolahan data yang telah dilakukan melalui penyebaran instrumen kepada 83 pengguna Iphone di
Komunitas Fanpage Facebook Iphone Indonesia, apabila di persentasekan skor tertinggi terdapat pada dimensi sensory experience sebesar $34,82 \%$ hal tersebut dikarenakan pengguna iphone melihat produk dan dapat menggambarkan pengalaman merek. Dimulai saat pandangan pertama produk, warna produk serta desain produk. Skor terendah diperoleh pada dimensi behavioral experience sebesar $10,82 \%$ hal tersebut disebabkan pengguna masih merasa belum puas dengan layanan serta produk yang diberikan. Kemudian iphone belum mampu membuat dan memfasilitasi sebuah komunitas, sehingga para pengguna iphone kurang merasakan kedekatan dengan merek ataupun dengan pengguna lain.

Dimensi yang memiliki skor yang tinggi yaitu sensory experience sedangkan dimensi yang memiliki skor paling rendah adalah behavioral experience. Dimensi sensory experience mengacu pada rangsangan yang berhubungan dengan penglihatan, pendengaran, penciuman, perasa dan sentuhan yang disajikan oleh merek. Dengan kata lain, dimensi sensorik mempresentasikan merek menarik yang dapat ditangkap oleh panca indera manusia. Sensorik ini merupakan dimensi yang akan membuat konsumen merasa bahwa merek memiliki kesan kuat dan menarik menurut indera mereka (Vincent, 2012).

Indikator pernyataan untuk mengukur dimensi sensory experience yang terdapat pada produk iphone di Indonesia. Perolehan skor tertinggi terdapat pada item pernyataan "Warna handphone iphone memberikan kesan elegan" sebesar 23,1\% dan "Kemenarikan desain dan model iphone" dengan skor yang sama. Sedangkan skor terendah terdapat pada item pernyataan "Fitur yang dimiliki iphone sesuai dengan kebutuhan sebesar 21,6\%. Kesan yang dapat diperlihatkan merek melalui panca indera menjadi fokus untuk memberikan kesan kuat dan menarik. Temuan ini sesuai dengan penelitian (Evans, 2011) yang menyatakan bahwa tampilan produk yang baik dapat mempengaruhi kepercayaan serta menjadi keterkaitan dengan merek.

Analisis dimensi behavioral experience bertujuan untuk memperoleh jawaban mengenai tindakan merek untuk memberikan kemudahan pengalaman sehingga menjadi sebuah kebiasaan dalam kehidupan sehari-hari. Berdasarkaan data yang diperoleh dari penyebaran kuesioner pada 
Komunitas Fanpage Facebook Iphone Indonesia menjelaskan bahwa tanggapan pengguna terhadap tindakan Iphone untuk merangsang kita untuk sesuatu atau mengubah perilaku kita sebagai hasil dari pengalaman

Pernyataan yang memiliki nilai tinggi dalam dimensi behavioral experience yaitu keinginan untuk terus membeli produk terbaru iphone walaupun dengan harga tinggi. Pernyataan tersebut sesuai dengan Barber, Kuo, Bishop, \& Jr (2012) bahwa cara lain untuk memeriksa perilaku konsumen adalah menilai kesediaan mereka untuk membayar lebih atau willingness to pay more sebagai harga maksimum yang bersedia dibayar oleh pembeli. Pernyataan yang memiliki skor paling rendah adalah Keinginan untuk bergabung pada komunitas.

Brand experience dimulai pada saat konsumen mencari produk, membeli, menerima pelayanan dan mengkonsumsi produk. Brand experience dapat dirasakan secara langsung maupun secara tidak langsung saat konsumen melihat iklan atau juga saat pemasar mengkomunikasikan produk melalui website (Kusuma, 2014). Penelitian (Bapat \& Thanigan, 2016) menunjukkan bahwa dimensi brand experience terdiri dari dua komponen utama yaitu affective brand experience and cognitive brand experience. Temuan menunjukkan bahwa dimensi affective brand experience dan cognitive brand experience mempengaruhi evaluasi merek secara positif. Selain itu, evaluasi merek secara keseluruhan adalah prediktor kuat bagi loyalitas merek.

Variabel selanjutnya yang diteliti adalah brand love. Berdasarkan hasil pengolahan data yang telah dilakukan melalui penyebaran kuesioner pada Komunitas Fanpage Facebook Iphone dapat diukur melalui perhitungan skor dimensi dari Brand Love. Skor total Brand Love sebesar 5339 sedangkan skor ideal brand love itu sendiri adalah 6860. Perbandingan ini menunjukan bahwa pada pelaksanaan brand love produk Iphone telah berlangsung dengan baik. Jumlah skor tersebut dimasukan dalam garis kontinum sebagai berikut:

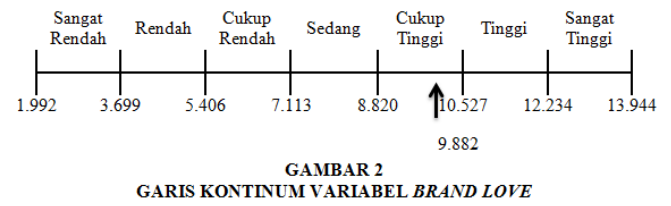

Secara ideal skor yang diharapkan untuk jawaban pengguna iphone terhadap pertanyaan nomor 16 sampai dengan 39 adalah 13.944. Perhitungan di atas menunjukan persentase sebesar $64,60 \%$ dari skor ideal yaitu 9.882, dengan perbandingan ini menunjukan bahwa brand love pada produk Iphone berada pada kategori cukup tinggi.

Secara keseluruhan variabel brand love (Y) yang terdiri dari self brand integration, passion driven behavior, positive emotional connection, long term relationship, anticipate separation distress dan attitude valence. Dapat diketahui kedudukannya berdasarkan skor yang di dapat dari rekapitulasi data. Rekapitulasi dimensi dari variabel brand love (Y) tersebut dapat dilihat dari Tabel 3 berikut:

Tabel 3

Rekapitulasi Tanggapan Mengenai Brand Love

\begin{tabular}{cllcc}
\hline No & Dimensi & $\begin{array}{c}\text { Perolehan } \\
\text { Skor }\end{array}$ & $\begin{array}{c}\text { Skor } \\
\text { Rata- } \\
\text { rata }\end{array}$ & (\%) \\
\hline 1 & $\begin{array}{l}\text { Self Brand } \\
\text { Integration } \\
\text { Passion } \\
2\end{array}$ & 2011 & 402,2 & 20,36 \\
& $\begin{array}{l}\text { Driven } \\
\text { Behavior } \\
\text { Positive }\end{array}$ & 2829 & 404,14 & 28,63 \\
3 & $\begin{array}{l}\text { Emotional } \\
\text { Connection } \\
\text { Long Term } \\
\text { Relationship }\end{array}$ & 1321 & 440,33 & 13,36 \\
& $\begin{array}{l}\text { Anticipate } \\
\text { Separation }\end{array}$ & 1075 & 358,33 & 10,88 \\
& $\begin{array}{l}\text { Distress } \\
\text { Atitude } \\
\text { Valence }\end{array}$ & 948 & 474 & 9,59 \\
\hline Total & 9882 & 2503,5 & 100 \\
\hline
\end{tabular}

Sumber: Hasil Pengolahan Data 2017

Temuan atau hasil pengolahan data menunjukan bahwa dimensi yang memperoleh skor tertinggi adalah dimensi passion driven behavior dengan presentase sebesar $28,63 \%$. Sedangkan tanggapan yang terendah adalah pada dimensi attitude valence dengan presentase sebesar 9,59\%.

Passion Driven Behaviors, Konsumen akan melakukan investasi berupa uang dan waktu, serta memiliki semangat yang penuh terhadap objek yang dicintai karena sering berinteraksi. Dimensi passion driven behavior diukur dengan indokator (1) Willingness ton invest resources, (2) Passionate desire to use dan (3) Things done in past. Willingness to invest resources, bersedia menghabiskan banyak waktu, uang dan energi untuk merek. Serta menghabiskan banyak waktu untuk belaja dan membelinya secara khusus. Passionate desire to 
use, rasa untuk menginginkannya, menggunakannya, dan merasakan kerinduan terhadap merek. Things done in past, merek telah terlibat di masa lalu, melakukan banyak hal serta terus berinteraksi.

Dimensi passion driven behavior memiliki skor tertinggi dikarenakan pelanggan merasakan keterikatan dengan iphone ketika pelanggan melakukan banyak hal bersama iphone. Perolehan skor tertinggi terdapat pada item pernyataan Keinginan terus menggunakan iphone sebesar 16,47\%, sedangkan skor terendah terdapat pada item Bersedia meluangkan waktu khusus untuk berbelanja membeli iphone sebesar 13,04\%.

Pelanggan yang sudah merasakan kecintaan terhadap merek akan, bersedia menghabiskan banyak waktu, uang dan energi untuk merek. Serta menghabiskan banyak waktu untuk belaja dan membelinya secara khusus. Passionate desire to use, rasa untuk menginginkannya, menggunakannya, dan merasakan kerinduan terhadap merek. Things done in past, merek telah terlibat di masa lalu, melakukan banyak hal serta terus berinteraksi (Lett, Bagozzi, Batra, \& Ahuvia, 2016)

Dimensi dengan skor terendah adalah attitude vaalence yang digambarkan dengan indikator sering membicarakannya kepada orang lain, sangat sering memikirkannya, merasakan kasih sayang. Dimensi attitude valence memberikan pengalaman dengan layanan dan produk berkualitas bagi pelanggan akan sangat memengaruhi tingkat kepuasan yang digambarkan sebagai prasyarat untuk loyalitas pelanggan (Kitapci, Dortyo, Yaman, \& Gulmez, 2013).

Dua dimensi lain yang digunakan dalam penelitian ini yaitu affective experience dan intellectual experience.

Analisis dimensi affective bertujuan untuk memperoleh jawaban mengenai kegiatan yang digunakan untuk menarik konsumen melalui pembentukan kepribadian merek tertentu. Dimensi affective experience mengacu pada kenyamanan pelanggan mendapatkan berbagai kemudahan dari produk tersebut (Y. H. Lin, 2015).

Analisis dimensi intellectual experience bertujuan untuk memperoleh jawaban mengenai penilaian pengalaman yang mendorong konsumen terlibat dalam pemikiran seksama mengenai keberadaan suatu merek. Jika pengalaman dan pemikiran yang telah tercipta pada benak konsumen (K. L. Keller, 2013).

\section{KESIMPULAN DAN REKOMENDASI}

Berdasarkan hasil penelitian yang telah dilakukan menggunakan analisis deskriptif, brand experience berada pada kategori tinggi. Sedangkan brand love berada pada kategori cukup tinggi.

Adanya penelitian ini diharapkan dapat membantu peneliti berikutnya dalam melakukan penelitian mengenai brand experience dan brand love dengan menggunakan indikator yang berbeda dari sumber teori yang lebih beragam, dan terhadap objek yang berbeda, karena masih banyaknya keterbatasan dalam penelitian ini, khususnya yang berkaitan dengan metode penelitian.

\section{DAFTAR PUSTAKA}

Airey, D. (2012). Logo design love: a guide to creating iconic brand identities.

Anggraeni, A., \& Rachmanita. (2015). Effects of Brand Love, Personality and Image on Word of Mouth; the Case of Local Fashion Brands Among Young Consumers. Procedia - Social and Behavioral Sciences, 211(September), 442-447.

Arora, S., \& Neha. (2016). Determinants of Customer-based Brand Equity: A Study of Public and Private Banks. Global Business Review, 17(4), 905-920. https://doi.org/10.1177/097215091664569 3

Bapat, D., \& Thanigan, J. (2016). Exploring Relationship among Brand Experience Dimensions , Brand Evaluation and Brand Loyalty. Global Business Review, 17(6), $1-16$. https://doi.org/10.1177/097215091666040 1

Barber, N., Kuo, P.-J., Bishop, M., \& Jr, R. G. (2012). Measuring psychographics to assess purchase intention and willingness to pay. Journal of Consumer Marketing, 29(4), 280-292. https://doi.org/10.1108/073637612112373 53

Batra, R., Ahuvia, A., \& Bagozzi, R. P. (2012). Brand Love. Journal of Marketing, 76(2), 1-16. https://doi.org/10.1509/jm.09.0339

Braskus, J. J., Schmitt, B. H., \& Zarantonello, L. (2009). Brand Experience: What Is It? 
How Is It Measured? Does It Affect Loyalty? Journal of Marketing, 73(May), 52-68.

Chen, A. C.-H., Chen, S. K., \& Ma, C.-L. (2016). Brand Experience and Customer Equity Prediction. Advances in Business and Management Forecasting, 19-38. https://doi.org/10.1108/S1477407020160000011003

Chu, S.-C., \& Kim, Y. (2011). Determinants of consumer engagement in electronic wordof-mouth (eWOM) in social networking sites. International Journal of Advertising, 30(1), 47. https://doi.org/10.2501/IJA-301-047-075

Cravens, D. W., \& Piercy, N. F. (2013). Strategic Marketing (10th ed.). New York: Mc Graw Hil.

Dirgantari, P. D. (2016). Peranan Bauran Pemasaran Jasa Pendidikan Terhadap Upaya Meningkatkan Ekuitas Merek Berbasis Pelanggan Perguruan Tinggi (Studi pada Perguruan Tinggi di Jawa Barat) Jurnal Pendidikan Manajemen Bisnis, 11, 22-31.

Dirgantari, P. D., Rahayu, A., \& Hurriyati, R. (2016). The Influence of Brand Element and Education Service Marketing Mix on Brand Momentum Of Higher Education Institution, (April 2014), 159-165.

Ekaputri, A. H., Rahayu, A., \& Wibowo, L. A. (2016). The Effect of Brand Experience on Customer Satisfaction and The Impact toward Repurchase Intention. Economics, Business and Management Research, 15, 464-467.

Evans, L. J. (2011). Fashion-brand experiences in multi-channel retailing: Impacts of experience dimensions and experience types on brand resonance. ProQuest Dissertations and Theses. University of North Texas. Retrieved from http://search.proquest.com.ezaccess.librar y.uitm.edu.my/docview/1046648580?acco untid $=42518$

Fetscherin, M., \& Conway, M. (2014). Brand Love: Interpersonal or Parasocial Love Relationship?

Fischer, M., Völckner, F., \& Sattler, H. (2010). How important are brands? A cross- category, cross-country study. Journal of Marketing Research, 47(5), 823-839. https://doi.org/10.1509/jmkr.47.5.823

Iglesias, O., Singh, J. J., \& Batista-Foguet, J. M. (2011). The role of brand experience and affective commitment in determining brand loyalty. Journal of Brand Management, 18(8), 570-582. https://doi.org/10.1057/bm.2010.58

Jung, H., \& Soo, M. (2012). the Effect of Brand Experience on Brand Relationship Quality. Academy of Marketing Studies Journal, 16(1), 2012.

Kang, A. (2015). Brand Love - Moving Beyond Loyalty An Empirical Investigation of Perceived Brand Love of Indian Consumer. Arab Economic and Business Journal, 10(2), 90-101. https://doi.org/10.1016/j.aebj.2015.04.001

Kataria, R. G. J. M. S. B. A. (2015). An investigation of antecendents and consequences of brand love in India. Journal of Business Administration, 7(3), 174-196.

Keller, K. (2013). Strategic brand management: Building, measuring, and managing brand equity (14th Editi). PEARSON.

Keller, K. L. (2008). Strategic Brand Management. Brand (Vol. 58). https://doi.org/10.2307/1252315

Keller, K. L. (2013). Strategic Brand Management.

Kim, Y. (2007). Towards Customer Love:Investigating The antecedents and outcome od satisfied customer's Emotional Attachment to retailers. Ph.d Thesis.

Kitapci, O., Dortyo, I. T., Yaman, Z., \& Gulmez, M. (2013). The paths from service quality dimensions to customer loyalty An application on supermarket customers. https://doi.org/10.1108/014091713113063 91

Kotler, P., \& Armstrong, G. (2013). Principles of Marketing (15th Editi). PEARSON.

Kotler, P., \& Keller, K. L. (2016). A FRAMEWORK FOR MARKETING 
MANAGEMENT. United State of America: PEARSON.

Kucuk, S. U. (2016). Brand hate: Navigating Consumer Negativity in the Digital World. Washington: Springer Nature.

Kusuma, Y. S. (2014). Pengaruh Brand Experience terhadap Brand Loyalty Yohanes Surya Kusuma Program Manajemen Pemasaran , Universitas KristenPetra J1 . Siwalankerto 121-131, Surabaya, 2(1), 1-11.

Kusume, Y. (2013). Brand Romance_Using the Power of High Design to Build a Lifelong Relationship with Your Audience. United Kingdom: Palgrave Macmillan.

Lett, M., Bagozzi, R. P., Batra, R., \& Ahuvia, A. (2016). Brand love : development and validation of a practical scale. Marketing Letters. $\quad$ https://doi.org/10.1007/s11002016-9406-1

Lin, C., Management, I., \& Cheng, N. (2013). Electronic Word of Mouth: The Moderating Roles of Product Involvement and Brand Image In International Conference on Technology Innovation and Industrial Management (pp. 29-47). Phuket, Thailand.

Lin, Y. H. (2015). Innovative brand experience's influence on brand equity and brand satisfaction. Journal of Business Research. https://doi.org/10.1016/j.jbusres.2015.06.0 07

Maholtra, K. N. (2010). Marketing Reseach: An Applied Orientation Sixth Ed Pearson Education (Sixth edit). Pearson Education.

Nysveen, H., Pedersen, P. E., \& Skard, S. (2012). Brand experiences in service organizations: Exploring the individual effects of brand experience dimensions. Journal of Brand Management, 20, 404423. https://doi.org/10.1057/bm.2012.31

Rahayu, A., \& Wibowo, L. A. (2013). Analisis Nilai Pengalaman Berbelanja Online Melalui Experiential Marketing. Jurnal Ilmu Manajemen Dan Bisnis, 4(1), 1-15.

Rodrigues, P., \& Reis, R. (2013). The Influence of " Brand Love" In Consumer Behavior
- The Case of Zara and Modalfa Brands. Proceedings of 22nd International Business Research Conference, (September), 9-10.

Roy, S. K., Eshghi, A., \& Sarkar, A. (2013). Antecedents and consequences of brand love. Journal of Brand Management, 20(4), 325-332. https://doi.org/10.1057/bm.2012.24

Saari, U. a., \& Mäkinen, S. J. (2017). Measuring brand experiences cross-nationally. Journal of Brand Management, (October 2016). https://doi.org/10.1057/s41262016-0022-4

Sallam, M. A. (2014). The Effects of Brand Image and Brand Identification on Brand Love and Purchase Decision Making: The Role of WOM. International Business Research, 7(10), 187-193. https://doi.org/10.5539/ibr.v7n10p187

Schmitt, B. (2009). The concept of brand experience. Journal of Brand Management, 16(7), 417-419. https://doi.org/10.1057/bm.2009.5

Smith, K., \& Hanover, D. (2016). Experiential Marketing: Secrets, Strategies, and Success Stories From The World's Greatest Brands. United State of America.

Steinberg, R. J. (1986). A Triangular Theory of Love, 93(2), 119-135.

Vincent, L. (2012). Brand Real: (How Smart Companies Live Their Brand Promise and Inspire Fierce Customer Loyalty). New York: AMACOM.

Wibowo, L. A. (n.d.). Experiential Marketing Pengaruhnya Terhadap Branded Customer Experience Dan Loyalitas Pelanggan Restoran Dan Cafe Serta Dampaknya Pada Citra Bandung sebagai Destinasi Pariwisata Indonesia. 